\title{
SHORT-TERM VARIABILITY IN THE PHYTOPLANKTON AND PHYSICO-CHEMICAL VARIABLES IN A HIGH-TIDAL REGIME, BAHÍA BLANCA ESTUARY, ARGENTINA
}

\author{
Valeria A. Guinder ${ }^{1 *}$, Cecilia A. Popovich ${ }^{2}$ and Gerardo M. E. Perillo ${ }^{l}$ \\ ${ }^{1}$ Instituto Argentino de Oceanografía (IADO-CONICET). \\ (Camino La Carrindanga km 7.5 (8000) Bahía Blanca, Argentina) \\ ${ }^{2}$ Laboratorio de Ficología y Micología, Universidad Nacional del Sur (UNS), \\ Departamento de Biología, Bioquímica y Farmacia. \\ (San Juan 670, (8000) Bahía Blanca, Argentina) \\ *Corresponding autor: vguinder@criba.edu.ar
}

\begin{abstract}
Hydrological processes such as advection, resuspension, estuarine circulation, internal waves, tidal stirring, vertical mixing and stratification are the main physical forces affecting the phytoplankton distribution in estuaries (DENMAN; GARGETT, 1983; CLOERN et al., 1989; CUSHING 1989; DE JONGE; VAN BEUSEKOM, 1992). Vertical and horizontal transport of phytoplankton in coastal areas could be induced by winds, water mass intrusions from the open sea, turbulence, freshwater inflow and tides (CLOERN et al., 1989; LI; SMAYDA, 2001; BRUNET; LIZON, 2003; HAGY III et al., 2005; POPOVICH; MARCOVECCHIO, 2008; POPOVICH et al., 2008b) and these sorts of transport are related to biomass accumulation and dispersion. Many studies have revealed intratidal variations in phytoplankton dynamics (e.g. DEMERS; LEGENDRE, 1979; DEMERS et al., 1986; DUSTAN; PINCKNEY, 1989; BRUNET; LIZON, 2003) and even differences in biomass between micro and macrotidal estuaries (MONBET, 1992). Moreover, phytoplankton patchiness in estuaries has been associated with the physical influence of tides (DUSTAN; PINCKNEY, 1989). In estuaries characterized by high-tidal energy, a steady phytoplankton composition over short time periods might be expected owing to the intense mixing processes continuously occurring in the water column. However, heterogeneous distributions of phytoplankton cells in the water column on different temporal and spatial scales have been observed (e.g. CUSHING, 1989; BRUNET; LIZON, 2003). Many studies have used the biomass (estimated by the chlorophyll $a$ concentration) as the main intrinsic property to describe the phytoplankton community dynamics during tidal cycles (DENMAN, 1977; FRÉCHETTE; LEGENDRE, 1982, CLOERN et al., 1989; DUSTAN; PINCKNEY, 1989; MONBET 1992), without taking into consideration the speciesspecific patterns related to these regular short-time events. Hence, studies based only on phytoplankton biomass variability throughout tidal cycles may
\end{abstract}

overlook the short-term temporal changes in the species composition.

The Bahía Blanca Estuary constitutes a mesotidal system with a semidiurnal cycle, the tides being the single most important input of energy (PERILLO; PICCOLO, 1991; PERILLO et al., 2004). The temporal and spatial dynamics of the phytoplankton in the estuary have been extensively studied (GAYOSO, 1998, 1999; POPOVICH; MARCOVECCHIO, 2008; POPOVICH et al. 2008a, $2008 \mathrm{~b}$ ) but none of these works has considered the short-term variability associated with the tidal cycle. The main goal of this study was to describe the temporal phytoplankton and physico-chemical dynamics over a short-time period at a fixed station under strong tidal influence. This study presents the first integrated description of daily phytoplanktoncommunity dynamics together with physical and chemical variables in the Bahía Blanca Estuary. Beside its local relevance, it is also a contribution to the understanding of the short-term variability in estuaries characterized by high tidal energy.

Bahía Blanca is a coastal plain estuary $\left(38^{\circ} 45^{\circ} \mathrm{S} ; 62^{\circ} 22^{\prime} \mathrm{W}\right)$ on the Atlantic coast of Argentina (Fig. 1). Tidal currents are reversible with maximum surface velocities of about $1.3 \mathrm{~m} \mathrm{~s}^{-1}$ and maximum vertically averaged values of 1.2 and $1.05 \mathrm{~m} \mathrm{~s}^{-1}$ for ebb and flood, respectively (PERILLO; PICCOLO, 1991). The fixed sampling site, Puerto Cuatreros station (mean depth $7.2 \mathrm{~m}$ ) is located in the inner zone of the estuary (Fig. 1). It is shallow and turbid, with a tidal range of up to $3.6 \mathrm{~m}$. Hourly measurements of phytoplankton and physico-chemical variables were carried out on 25 July 2006. Profiles of $\mathrm{pH}$, salinity and temperature were measured with a digital multisensor Horiba U-10. Using a radiometer LI-COR model LI-192SB, PAR (photosynthetically active radiation) light intensity received at the pier $\left(I_{\mathrm{a}}\right)$, at the water surface $\left(I_{0}\right)$ and vertical profiles of PAR in the water column were obtained. From these profiles, the light extinction coefficient $(\mathrm{k})$ was estimated. The mean light intensity in the mixed layer 
$\left(I_{\mathrm{m}}\right)$ was calculated from the equation (RILEY, 1957): $I_{\mathrm{m}}=I_{0}\left(1-\mathrm{e}^{(-\mathrm{kZm})}\right)\left(\mathrm{k} \mathrm{Z}_{\mathrm{m}}\right)^{-1}$, where $\mathrm{Z}_{\mathrm{m}}$ is the mixed zone. Wind measurements were obtained every 5 minutes by a meteorological base installed on the pier. Using a 2.51 Van Dorn bottle, surface and bottom samples ( $1 \mathrm{~m}$ above the sea bottom) were collected to determine dissolved nutrients, chlorophyll $a$, phytoplankton, particulate suspended matter (PSM) and particulate organic matter (POM) concentrations. Dissolved nutrients were determinated by standardized methods using a Technicon AA-II Autoanalyzer and Chlorphyll $a$ was measured spectrophotometrically in accordance with APHA (1998). The samples used for cellular enumeration were preserved in Lugol's solution. The cell counts were undertaken using a Sedgwick-Rafter chamber $(1 \mathrm{ml})$. The entire chamber was examined at $\mathrm{x} 200$, and each algal cell was counted as a unit. For qualitative phytoplankton analysis, samples were taken with a Nansen net $(30 \mu \mathrm{m}$ mesh), fixed with formaldehyde (final concentration $0.4 \%$ ) and analyzed using a Nikon Eclipse microscope with magnification of x1000 and phase contrast. PSM and POM were determined gravimetrically filtering 300$500 \mathrm{ml}$ of water through $\mathrm{GF} / \mathrm{F}$ filters (pore diameter = $0.7 \mu \mathrm{m})$.

The fixed point sampling strategy employed for this hourly survey in the inner zone of the Bahía Blanca Estuary, even if it did not give information on the spatial behavior of the variables measured, showed a detailed evolution through the tidal cycle. Tide and wind have been considered the principal factors controlling the water turbulence processes in the inner zone of the estuary (CUADRADO; PERILLO, 1997; PERILLO et al., 2001). These factors regulate the water turbidity by inducing sediment resuspension from the bottom and horizontal transport of sediments from the coast, tidal flats and islands (CUADRADO; PERILLO, 1997; CUADRADO et al., 2005). In this study, the wind effect was nearly insignificant during the sampling period: with mean wind velocities of $0.13 \mathrm{~m} \mathrm{~s}^{-1}$ in the morning (SSW predominant direction) and $2.38 \mathrm{~m} \mathrm{~s}^{-1}$ in the afternoon (dominant direction from the $S$ ). Therefore, the short-term variability observed in the variables measured was mainly due to tidal influence. Tidal height fluctuated between 6 and $9.05 \mathrm{~m}$ (Fig. 2a), low water slack occurred at 13:05 $\mathrm{h}$ and high water slacks at 7:08 and 19:05 h (local time). Water salinity co-varied with tidal height (Fig. 2b), giving the lowest salinity at low water, consistent with the expected result of the advection of the lateral salinity gradients typical of an estuary with major freshwater input at the head. The $\mathrm{pH}$ remained relatively constant $(\Delta \mathrm{pH}=0.17)$ over time while weak temperature variations $(\Delta \mathrm{T}=0.9)$ were observed during the sampling period (Fig. 2b). Dissolved nitrate, ammonium and phosphate concentrations showed an erratic behaviour over time (coefficient of variation, $\mathrm{CV}$ up to $20 \%$ for ammonium) (Fig. 3a,b). None of these dissolved

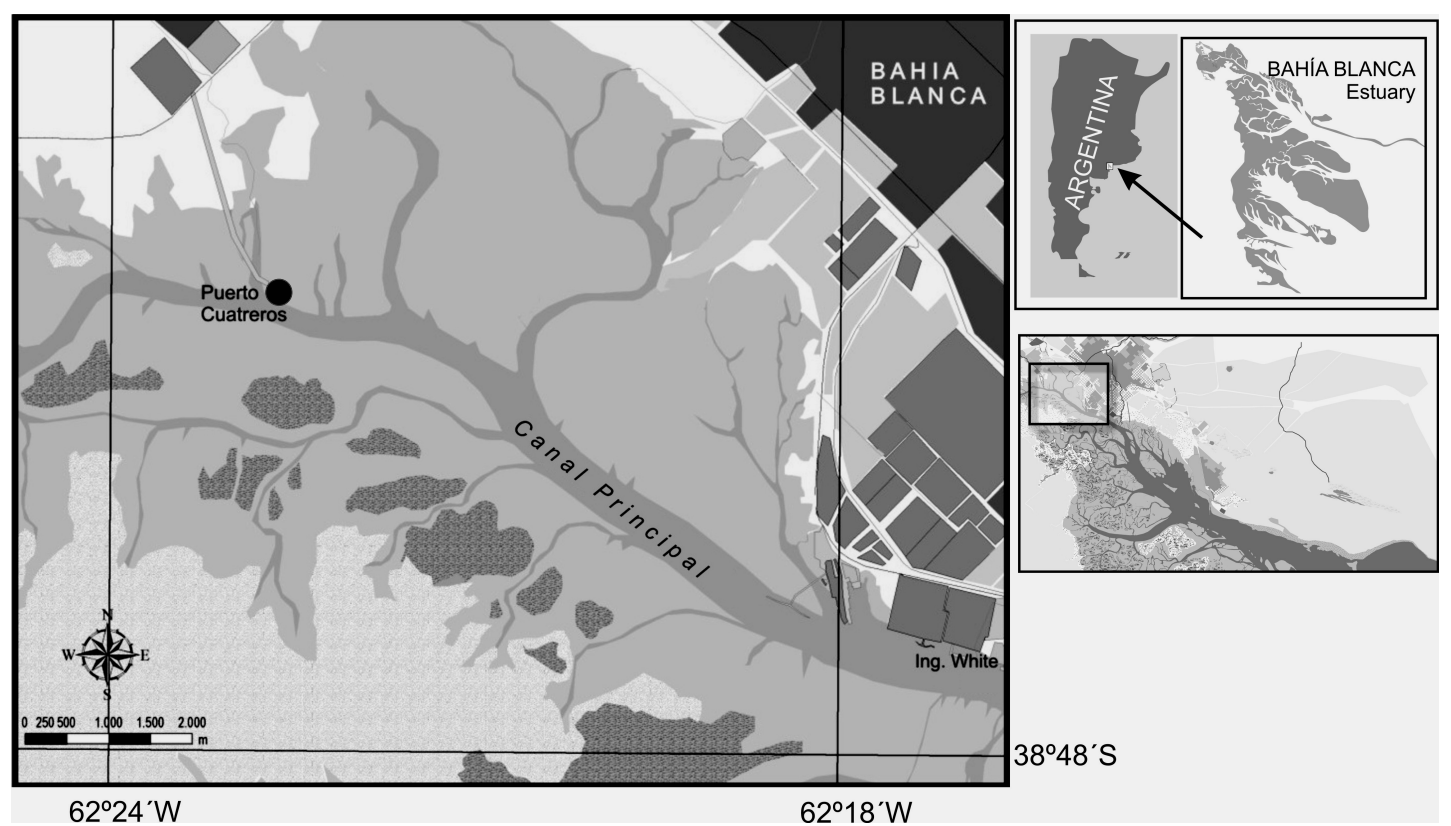

Fig. 1. The location of the study site, Puerto Cuatreros, in the inner zone of the Bahía Blanca Estuary, Argentina. 
nutrients described a pattern which could be associated with the tidal cycle. The strength of the tidal currents and the mixing processes might induce an intense vertical nutrient cycling (e.g. PHILLIPS et al., 2005). Nitrite concentration (Fig. 3a) seemed to be associated with the tidal movement since it showed a gradual tendency to decrease around low tide. Silicate concentration described a clearer temporal tendency (Fig. 3c), opposite to the tidal height (Spearman correlation, $\left.\mathrm{r}_{\mathrm{s}}=-0.98, \mathrm{p}<0.01\right)$. Freije et al. (2008) observed that dissolved silicate is more concentrated in the sediments than in the water column in the inner zone of the Bahía Blanca Estuary. This suggests that sediment removal from the bottom might be greater during low tide, contributing with a high concentration of silicates to the plankton habitat. Nutrient release from sediments has been commonly observed in coastal systems affected by resuspension processes (e.g. PHILLIPS et al., 2005).
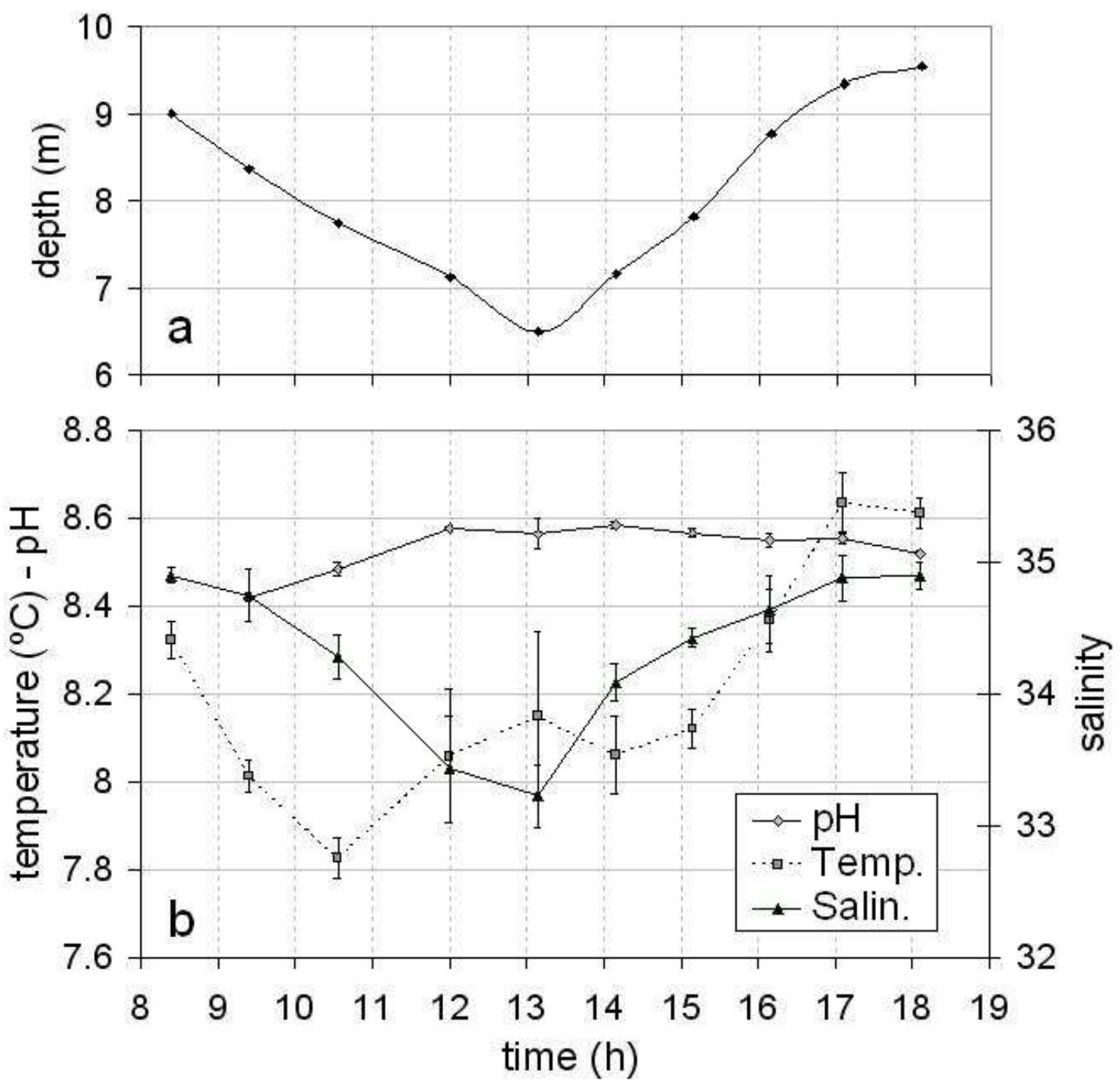

Fig. 2. Temporal evolution of (a) water column height and (b) physical parameters (temperature, $\mathrm{pH}$ and salinity) measured in situ at the study site. Vertical bars represent the standard deviation of the vertical profiles. 


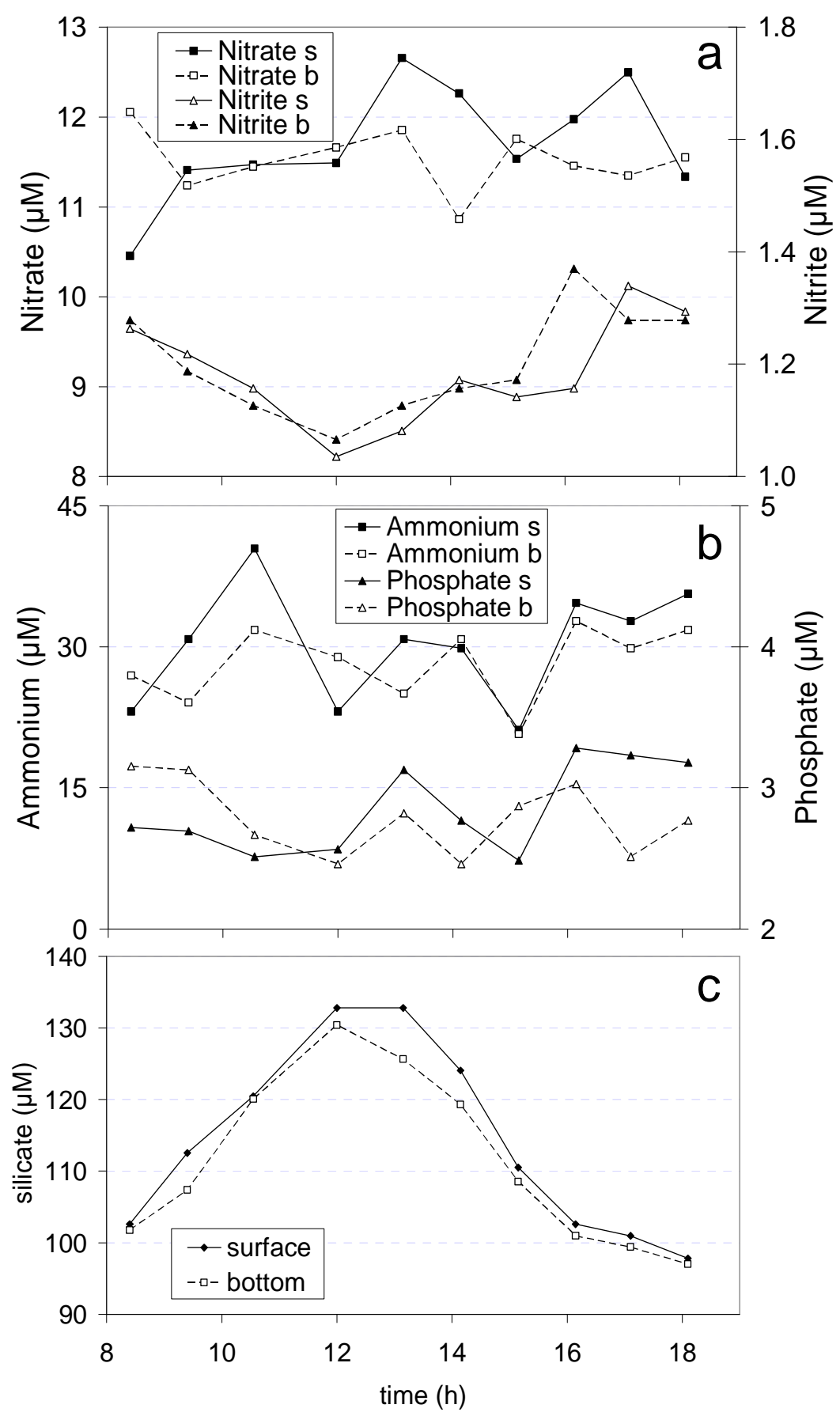

Fig. 3. Temporal evolution of dissolved nutrient concentrations at the surface, $s$, and at the bottom, b, of the water column at the study site. (a) Nitrite and nitrate, (b) ammonium and phosphate and (c) silicate concentration. 
The water column was always vertically mixed as indicated by temperature and salinity profiles; hence water column depth was considered as an indicator of mixed zone depth $\left(\mathrm{Z}_{\mathrm{m}}\right)$. The light intensity at the water surface $\left(I_{0}\right)$ varied according to $I_{\mathrm{a}}$ (Fig. $\left.4 \mathrm{a}\right)$ and both were affected by cloudiness. The mean light intensity in the mixed layer $\left(I_{\mathrm{m}}\right)$ showed an irregular pattern over the sampling period and was affected by $I_{0}$ and water turbidity since it decreased markedly at $14 \mathrm{~h}$ (fig. $4 \mathrm{a}$ ), coinciding with the highest value of the light extinction coefficient, $\mathrm{k}=6.04 \mathrm{~m}^{-1}$ (Fig. 4b). In shallow and turbid estuaries characterized by high tidal energy such as the Bahía Blanca Estuary, the rapid vertical mixing may induce changes in the suspended sediment concentrations (CLOERN et al., 1989; VAN DE KREEKE et al., 1997; VELEGRAKIS et al., 1997; CUADRADO; PERILLO, 1997). In addition, short-term fluctuations in water turbidity generate more variable light exposures affecting the phytoplankton populations (ALPINE; CLOERN, 1988; MONBET, 1992). Thus, under strong tidal regimes, the effects of vertical mixing on the phytoplankton community are generally not direct; the effects are, rather, mediated through the agency of light conditions (FRECHÉTTE; LEGENDRE, 1982; DEMERS et al., 1986) which depend on the daily cycle of solar radiation and on the amount of PSM.

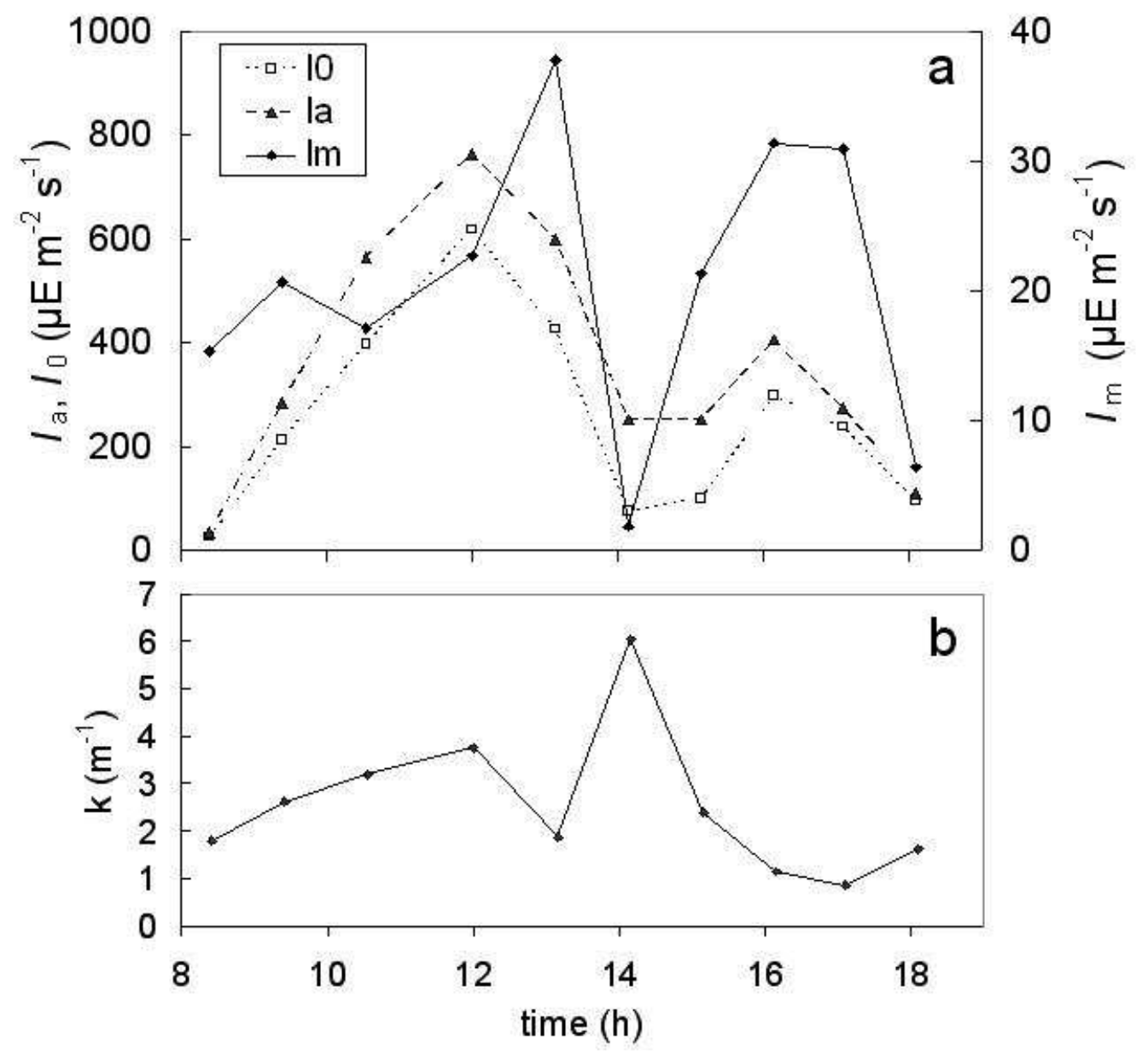

Fig. 4. Temporal evolution of light parameters at the study site. (a) Light intensity out of the water $\left(I_{\mathrm{a}}\right)$, at the water surface $\left(I_{0}\right)$ and light intensity in the mixed layer $\left(I_{\mathrm{m}}\right)$. (b) Light extinction coefficient $(\mathrm{k})$. 
The PSM concentration showed different temporal patterns at the surface and at the bottom of the water column (Fig. 5a,b). For the higher elevations of the PSM at the surface the major contribution was around low tide, while at the bottom it was at the beginning of the flood. The amount of PSM and POM were slightly higher at the bottom than at the surface, probably they were removed from the sea floor by tidal currents (CUADRADO; PERILLO, 1997). Other researches into the tidal variability of the PSM concentration in estuaries have reported different patterns of the tidal cycle associated with advection and resuspension (WEEKS et al., 1993; VAN DE KREEKE et al., 1997; VELEGRAKIS et al., 1997; ELLIS et al., 2004). In these works, a wide range of short-term variability of PSM concentration has been observed ranging from in phase with the tidal movement to erratic behaviour. Although the length of the time series obtained by this approach at the Puerto Cuatreros station was not enough to explain the physical mechanisms that regulate the variability of the PSM concentrations, our results together with the

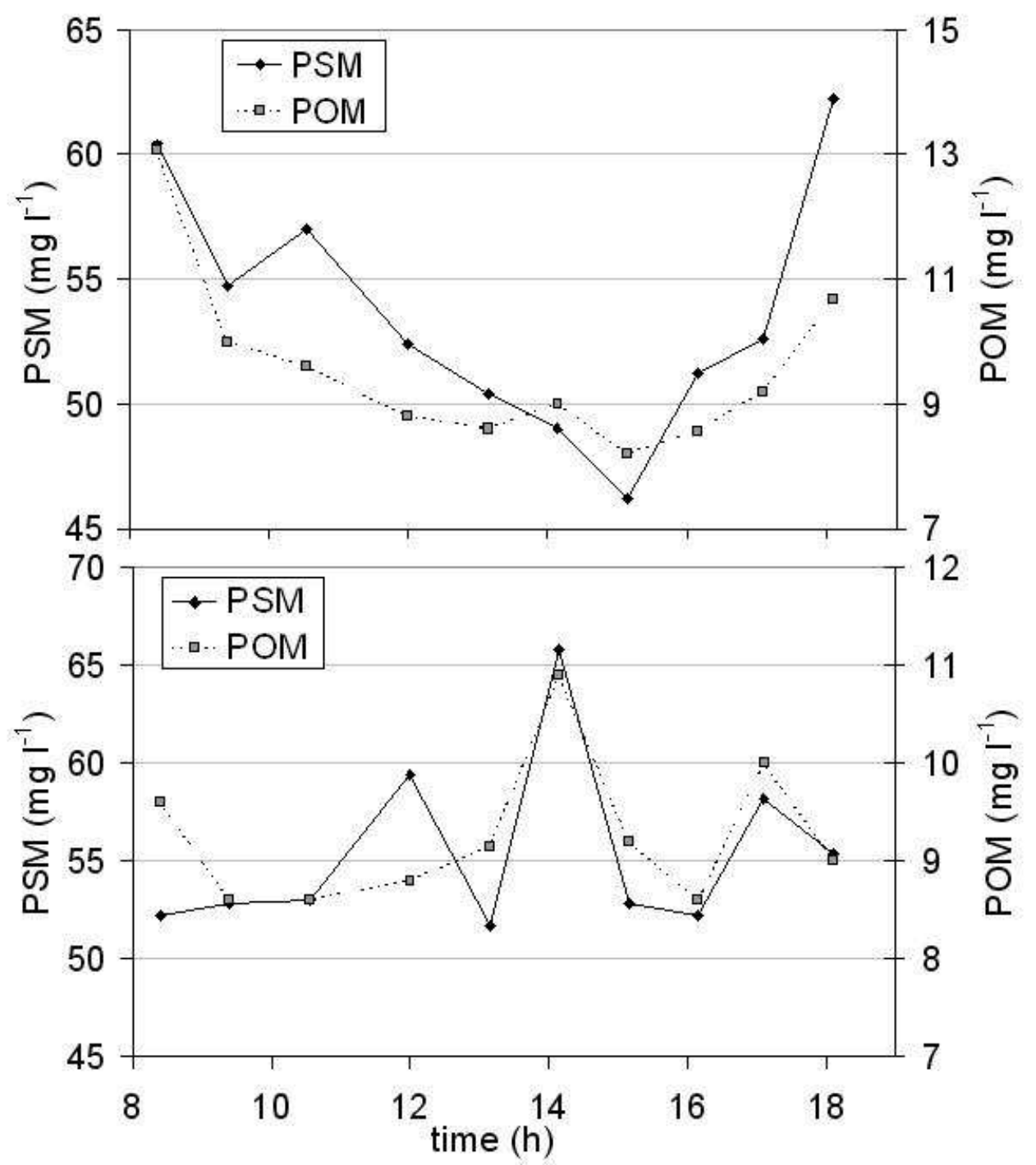

Fig. 5. Temporal evolution of particulate suspended matter and particulate organic matter at the study site: (a) at the surface and (b) at the bottom of the water column. 
observations of other researches highlight the diverse responses of the suspended particles to water movements in high energy regimes. In addition, for periods of $1 \mathrm{~h}$, variations in chlorophyll concentration (Fig. 6a) and phytoplankton abundance (Fig. 6b) took on a stochastic character. The chlorophyll concentration varied about $50 \%$ from its tidal mean, suggesting that the short-term variability results simply from the tidal advection (CLOERN et al., 1989). The phytoplankton abundance showed a CV of $28 \%$ at the surface and $33 \%$ at the bottom, and cellular densities were higher at the upper layer of the water column almost throughout the study period (Fig. $6 b)$. The phytoplankton community was mostly represented by diatoms and tidal stirring seemed to affect some species more than others (Fig. 7). As diatoms have passive movements, they behaved as relatively passive particles, so their concentration and distribution depended mainly on the water displacements. Moreover, it has been observed that the effects of turbulence processes (resuspension and advection) on particle concentrations are related to the

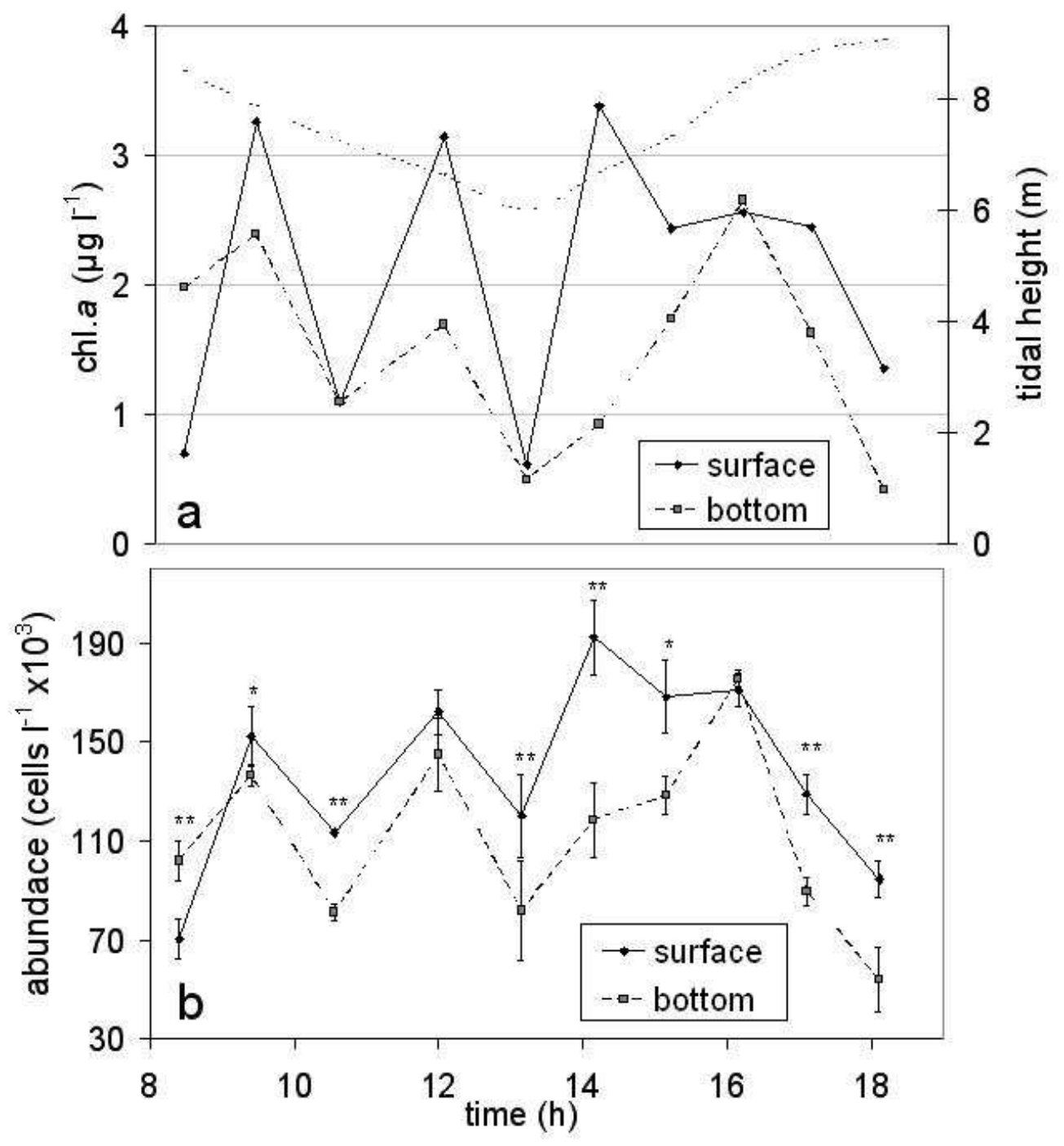

Fig. 6. Temporal evolution of (a) chlorophyll $a$ variation and (b) phytoplankton cellular abundance at the surface and at the bottom of the water column at the study site. Tidal height is illustrated by the dotted line in fig. (a). Mann-Whitney tests were used between the mean values of cellular abundances (subjected to logarithmic transformation) for surface and bottom waters for every sampling hour: ** $\mathrm{p}<0.01, * \mathrm{p}<0.05$. 
particle size and shape and the aggregation/disaggregation properties (VAN DE KREEKE et al., 1997; VELEGRAKIS et al., 1997; KIØRBOE et al., 2001; ELLIS et al., 2004). In this study, diatoms arranged in chains, with mucilage threads and/or silicon setae, such as Thalassiosira spp. (cell diameter: 10 - $45 \mu \mathrm{m}$ ) and Chaetoceros spp. (8 $34 \mu \mathrm{m})$, seemed to be affected in a different way by water turbulence and tidal stirring than the smaller, solitary species without cell projections, such as Cyclotella spp. $(6-13 \mu \mathrm{m})$ and Miniduscus chilensis $(5-9 \mu \mathrm{m})$. The first group showed relatively higher abundances around high tide whereas the latter appeared to be more abundant at low tide (Fig. 7). As a first approach to a possible explanation, we suggest that their cells' sizes, shapes, life styles (chains vs. solitary cells) and their ability to aggregate or disaggregate as also their sinking rates are closely related to this phenomenon. Further studies over longer periods should be undertaken to detect possible patterns of phytoplankton species dynamics related to tidal processes. The presence of benthic diatoms (e.g. Gyrosigma sp., Fragilaria spp., Nitzschia spp. and Surirella sp.) in the plankton habitat in the inner zone of the Bahía Blanca Estuary was of considerable importance over the tidal cycle, especially in the bottom samples. This observation is common in shallow coastal systems where benthic species are released into the water column due to resuspension processes induced by tides (BRUNET; LIZON, 2003). Moreover, in tidal flats, the fluxes of microphytobentos between sediment and water due to tidal and wind effects (DE JONGE; VAN BEUSEKOM, 1995) play a crucial role in the system, functioning by supplying food for the pelagic copepods (DE JONGE; VAN BEUSEKOM, 1992).
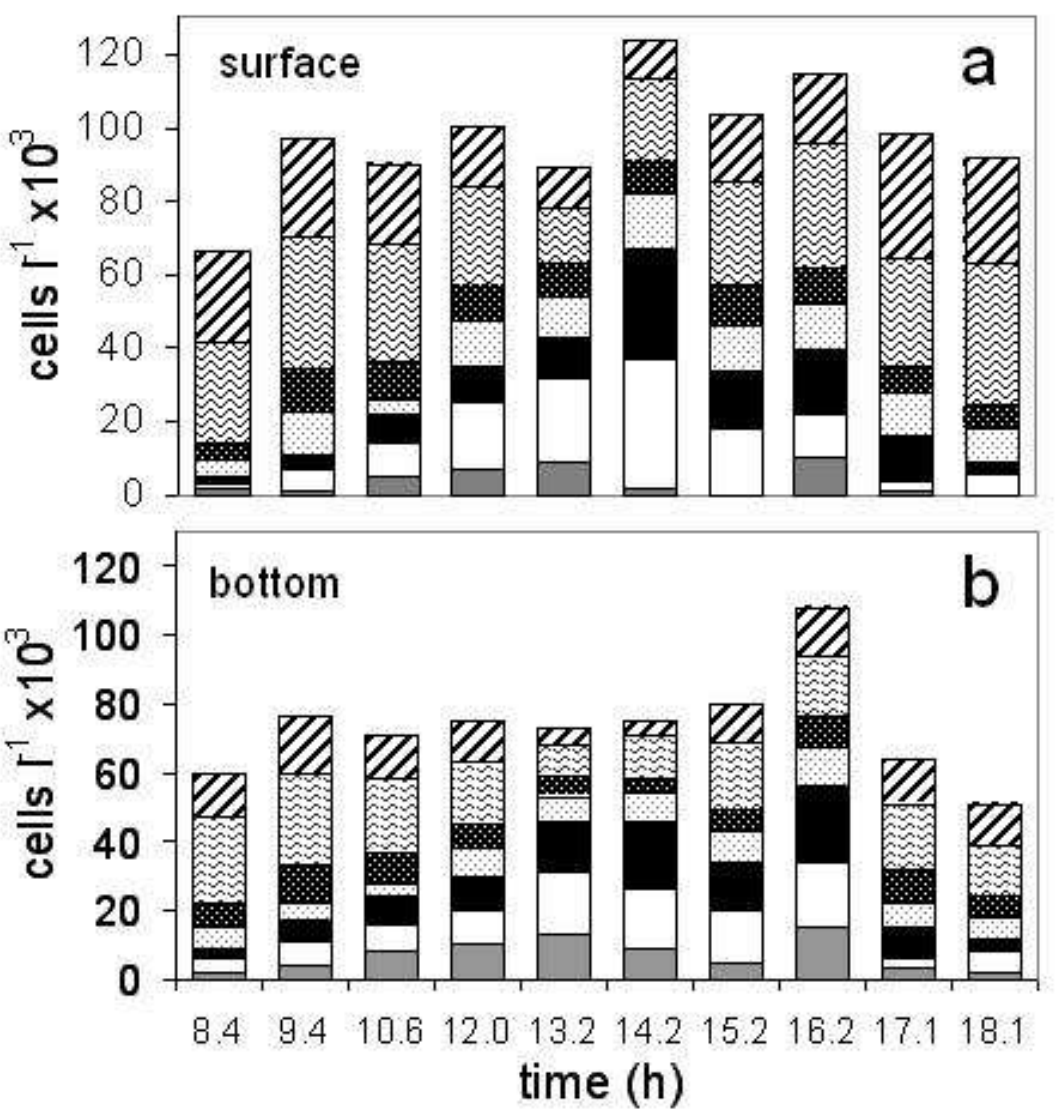

E Chatoceros spp.

匪 $T$. eccentrica

in $T$. cumiseriata

ᄂ G. delicatula

Cyciotella sp.

$\sqsubset M$. chilensis

Benthic species

Fig. 7. Temporal evolution of the abundances of the most frequent diatom species, (a) at the surface and (b) at the bottom of the water column at the study site. 
Considering that estuaries are extremely heterogeneous systems, this short-term study represents a contribution to the knowledge of the dynamics of estuarine phytoplankton and physicochemical variables over tidal time scales. The present study is just a snapshot of what happened on a given day under particular environmental conditions, so it is not appropriate to generalize these results as if they applied to every tidal coastal system. Several extensions of this study are needed. Nevertheless, the most relevant contribution of this research is that it shows how variable the phytoplankton community structure and the physico-chemical properties of the water column can be over short time scales in mesotidal estuaries. This variability should be taken into consideration for every phytoplankton monitoring program undertaken in high energy regimens.

\section{ACKNOWLEDGEMENTS}

We wish to thank Alejandro Vitale for his participation in the field work and Raúl Astesuain, Armando Astesuain and Javier Arlengui for the analytical determination of chlorophyll and dissolved nutrients. We also thank Walter Melo for drawing the map of the estuary.

\section{REFERENCES}

ALPINE, A. E.; CLOERN; J. E. Phytoplankton growth rates in a light-limited environment, San Francisco Bay. Mar. Ecol. Prog. Ser., v. 44, p. 167-173, 1988

APHA - AMERICAN PUBLIC HEALTH ASSOCIATIONChlorophyll. In: Standard methods for the examination of water and wastewater. 20th ed. Washington, DC, , 1998. p. 10-25.

BRUNET, C.; LIZON, F. Tidal and periodicities of sizefractionated phytoplankton pigment signatures at an offshore station in the southeastern English Channel. Estuar. coast. Shelf Sci., v. 56, p. 833-843, 2003.

CLOERN, J.E.; POWELL, T.M.; HUZZEY, L.M. Spatial and temporal variability in south San Francisco Bay (USA). II. Temporal changes in salinity, suspended sediments, and phytoplankton biomass and productivity over tidal time scales. Estuar. coast. Shelf Sci., v. 28, p. 599-613, 1989.

CUADRADO, D. G.; PERILlO, G. M. E. Migration of intertidal sand bank at the entrance of the Bahía Blanca Estuary, Argentina. J. coast. Res., v. 13, p. 139-147, 1997.

CUADRADO, D. G.; GÓMEZ, E. A.; GINSBERG, S. S. Tidal and longshore sediment transport associated to a coastal structure. Estuar. coast. Shelf Sci., v. 62, p. 291-300, 2005.

CUSHING, D. H. A difference in structure between ecosystems in strongly stratified waters in those that are only weakly stratified. J. Plankt. Res., v. 11, n. 1, p. 113, 1989.

DE JONGE, V. N.; VAN BEUSEKOM, J. E. E. Contribution of resuspended microphytobenthos to total phytoplankton in the Ems estuary and its possible role for grazers. Neth. J. Sea Res., v. 30, p. 91-105, 1992.

DE JONGE, V. N.; VAN BEUSEKOM, J. E. E. Wind and tide induced resuspension of sediment and microphytobenthos from tidal flats in the Ems estuary. Limnol. Oceanogr., v. 40, p. 766-778, 1995.

DEMERS, S.; LEGENDRE, L. Effets des marées sur la variation circadienne de la capacité photosynthétique del phytoplancton du l'estuaire du St. Laurent. J. expl mar. Biol. Ecol., v. 39, p. 87-99, 1979.

DEMERS, S.; LEGENDRE, L.; THERRIAULT, J. C. Phytoplankton response to vertical tidal mixing. In: BOWMAN, M.; YENTSCHS, C. M.; PETERSON, W. T. (Ed.). Lecture notes on coastal and estuarine studies: 17. Berlin: Springer-Verlag, 1986. p. 1-40.

DENMAN, K. L. Short term variability in vertical chlorophyll structure. Limnol. Oceanogr., v. 22, n. 3, p. 434-441, 1977.

DENMAN, K. L.; GARGETT, A. E. Time and space scales of vertical mixing and advection of phytoplankton in the upper ocean. Limnol. Oceanogr. 28, p. 801-815, 1983.

DUSTAN, P.; PINCKNEY, J. L. Tidally induced phytoplankton patchiness. Limnol. Oceanogr., v. 34, n. 2, p. 410-419, 1989.

ELLIS, K. M.; BOWERS, D. G.; JONES, S. E. A study of the temporal variability in particle size in a high-energy regime. Estuar. coast. Shelf Sci., v. 61, p. 311-315, 2004.

FRÉCHETTE, M.; LEGENDRE, L. Phytoplankton photosynthetic response to light in an internal tide dominated environment. Estuaries, v. 5 , n. 4, p. 287293, 1982.

FREIJE, R. H.; SPETTER, C. V.; MARCOVECCHIO, J. E.; POPOVICH, C. A.; BOTTÉ, S. E.; NEGRÍN, V.; ARIAS, A.; DELUCCHI, F.; ASTESUAIN, R. O. Water chemistry and nutrients of the Bahía Blanca Estuary. Perspectives on integrated coastal zone management in South America. NEVES, R.; BARETTA, J.; MATEUS, M. (Ed). Lisboa: IST Press, 2008. p 243256.

GAYOSO, A. M. Long-term phytoplankton studies in the Bahia Blanca Estuary, Argentina. ICES J. mar. Sci., v. 55 , p. 655-660, 1998.

GAYOSO, A. M. Seasonal succession patterns of phytoplankton in the Bahía Blanca Estuary (Argentina). Bot. mar., v. 42, p. 367-375, 1999.

HAGY, J. D.; III; BOYNTON, W. R.; JASINSKI, D. A. Modelling phytoplankton deposition to Chesapeake Bay sediments during winter-spring: interannual variability in relation to river flow. Est. Coast. Shelf Sci. 62, p. 25-40, 2005.

KIØRBOE, T.; PLOUG, H.; THYGESEN, U.H. Fluid motion and solute distribution around sinking aggregates. I. Small-scale fluxes and heterogeneity of nutrients in the pelagic environment. Mar. Ecol. Prog. Ser., v. 211, p. 1-13, 2001.

LI, Y.; SMAYDA, T. J. A cholophyll time series for Narragansett Bay: Assessment of the potential effect of tidal phase on measurement. Estuaries, v. 24, n. 3, p. 328-336, 2001.

MONBET, Y. Control of phytoplankton biomass in estuaries: a comparative analysis of microtidal and macrotidal estuaries. Estuaries, v. 14, n. 4, p. 563-571, 1992. 
PERILLO, G. M. E.; PICCOLO, M. C. Tidal response in the Bahía Blanca Estuary, Argentina. J. coast. Res., v. 7, p. 437-449, 1991.

PERILLO, G. M. E.; PICCOLO, M. C.; PARODI, E.; FREIJE, R. H. The Bahía Blanca Estuary. In: SEELIGER U., KJERFVE B. (Ed.). Coastal marine ecosystems of Latin America. Berlin-New York: Springer-Verlag, 2001. p. 205-217. Ecological Studies, v. 144.

PERILLO, G. M. E.; PICCOLO, M. C.; PALMA, E.; PÉREZ, D.; PIEREINI, J. Oceanografía física. In: PICCOLO, M. C.; HOFFMEYER, M. S. (Ed.) El ecosistema del estuario de Bahía Blanca. Bahía Blanca, Argentina: Instituto Argentino de Oceanografía, 2004. p. 61-67.

PHILLIPS, I. R.; BURTON, E. D; HAWKER, D. W. Effect of diffusion and resuspension on nutrient release from submerged sediments. Toxicol. Environ. Chem., v.87, n. 3 , p. $373-388,2005$.

POPOVICH, C. A.; MARCOVECCHIO, J. E. Spatial and temporal variability of phytoplankton and environmental factors in a temperate estuary of South America (Atlantic coast, Argentina). Cont. Shelf Res., v. 28, p. 236-244, 2008.

POPOVICH, C. A.; SPETTER, C. V.; MARCOVECCHIO, J. E.; FREIJE, R. H. Nutrient availability during winter diatom bloom in a shallow and well-mixed estuary (Bahía Blanca, Argentina). J. coast. Res., v. 24, n. 1, p. 95-102, 2008a.
POPOVICH, C. A.; GUINDER, V. A.; PETTIGROSSO, R. Composition and dynamics of phytoplankton and aloricate ciliate communities in the Bahía Blanca Estuary. In: Perspectives on integrated coastal zone management in South America. NEVES, R.; BARETTA, J.; MATEUS, M. (Ed). Lisboa: IST Press, 2008b. p 257-272.

RILEY, G. A. Phytoplankton of the North Central Sargasso Sea. Limnol. Oceanogr., v. 2, p. 252-270, 1957.

VAN DE KREEKE, J.; DAY, C. M.; MULDER, H. P. J. Tidal variations in suspended sediment concentration in the Ems estuary: origin and resulting sediment flux. J. Sea Res., v. 38, p. 1-16, 1997.

VELEGRAKIS, A. F.; GAO, S.; LAFITE, R.; DUPONT, J. P.; HUAUlT, M. F.; NASH, L. A.; COLlinS, M. B. Resuspension and advection processes affecting suspended particulate matter concentrations in the central English Channel. J. Sea Res., v. 38, p. 17-34, 1997.

WEEKS, A. R.; SIMPSON, J. H.; BOWERS, D. The relationship between concentrations of suspended particulate matter and tidal processes in the Irish Sea. Cont. Shelf Res., v. 13, p. 1325-1334, 1993.

(Manuscript received 11 November 2008; revised 27 February 2009; accepted 29 May 2009) 